\title{
Indonesian Legal Remedies Againts Tiongkok and Vietnam Dumping in Indonesia
}

\author{
Rahmadi Indra Tektona \\ Faculty of Law, Universitas Jember \\ e-mail: rahmadiindra@unej.ac.id \\ Nuzulia Kumala Sari \\ Faculty of Law, Universitas Jember \\ e-mail: nuzuliakumala@unej.ac.id \\ Amru Hanifa Mukti \\ Faculty of Law, Universitas Jember \\ e-mail: amruhanifa@unej.ac.id
}

\begin{abstract}
Indonesia has a problem increasing the number of iron and steel imports from year to year, but Tiongkok and Vietnam are highlighted differently by government because they have experienced a significant increase, so they are suspected of dumping. And than, what the legal remedies should be taken against the alleged dumping carried out by Tiongkok and Vietnam by competent institutions and related parties and what the legal consequnces are. This research will be analyzed with normative legal research principles, legal doctrines, and international agreements with the law approach and conceptual approach.The Antidumping Code is the basis of Indonesia's efforts towards Tiongkok and Vietnam given that the three countries are remembers of the World Trade Organization with General Agreement on Tariff and Trade. The Indonesian Anti-Dumping Committee is an institution that is given the authority to conduct dumping investigations, both offensively or defensively wich is inisiated based on initiatives or requests from the majority of the Domestic Industry of the similar goods. If the investigation process carried out by KADI is proven to be found dumping it will be subject sanctions in the form of the imposition of Anti-Dumping Import Duty according to the amount of dumping margin and if it is not found or deministic margin then the investigation process is terminated. And it is unfortunate because dumping specifically has not been regualated in a law in Indonesia.
\end{abstract}

Keywords: Dumping, Legal remedies, Legal consequences.

\section{INTRODUCTION}

Trade protective policies were often taken in the pre-18th century which only affected some people (mercantilists) whose control under the merchants and political rulers, and the rest of them got poverty. Adam Smith argues that this policy inhibits and causes a decline in international trade which has implications for the slow development and prosperity of nations. After the Second World War, protection and fraudulent trade were again carried out by countries as a form of maintaining their economy and had an impact on production factors which the result is consumers having difficulty obtaining good quality things with competitive prices. 
The United States led the initiation of multilateral trade with its trading partners, especially the UK, thus create two frameworks of thought, namely the Repriocal Trade Agreement Act, 1934 and the 1947 General Agreement on Tariff and Trade (GATT). The regulation regarding dumping was only poured out a year later in Article VI because of the many state policies that caused losses and unfair treatment which resulted in the bankruptcy of the Domestic Industry. The refinement of the dumping regulation regulations was continuously refined meeting after meeting so that the creation of the 1994 Antidumping Code replaced the 1979 Antidumping Agreement which was legally signed in conjunction with the Estabilishing Agreement of the World Trade Organization (WTO).

Dumping is a problem that often highlighted, because it is a fraudulent practice that often occurs in the context of international trade which can cause losses to the economic activities of the country, where the dumping is carried out. Anti-dumping policies are provisions that highlight dumping practices and imposition of sanctions in international trade. This is because dumping is an action cause a loss to the country's economy, so the state needs protection. In accordance with what is stipulated in the Anti-dumping Code1994, as this provision applies, the state may take action in the form of imposition of anti-dumping duties on the basis of an investigation by the antidumping commission. However, the anti-dumping import duty imposed is not a retaliatory measure that can harm producers and benefit the domestic market, but rather an import duty that is imposed so as to prevent (equal) price imbalance for domestic products and to be able to compete fairly. The amount of anti-dumping duties imposed will not exceed the difference between dumping and normal prices (dumping margin). ${ }^{2}$

The iron and steel industry continues to develop in the international market, in the development and advancement of knowledge of meeting the needs of the infrastructure development sector, transportation equipment, mining equipment, industry, to the needs of roofs and walls in households. Indonesia was recorded that in 2017 , it consumed 13.59 million tons of steel per year with a production value of $48 \%$ or around 6.5 million tons per year and imports of $52 \%$ or around 7 million tons per year. Iron and steel commodities are recorded as the 3rd largest imported commodity at $6.45 \%$ of total imports or around US $\$ 10.25$ billion. However, imported products in the form of Zinc Aluminum Armored Steel (BjLAS) originating from the People's Republic of China and Vietnam are in the spotlight because they have increased quite significantly over the last 3 years, namely $27 \%$ recorded since 2016 amounting to 463,375 tons per year to become 748,400 tons per year in 2018 , besides that the two products from the two countries have a dominant value of $90 \%$ of the total BjLAS in Indonesia. ${ }^{3}$

Based on Article 5 of Government Regulation Number 34 Year 2011 concerning Antidumping Measures, Compensation Measures, and Trade Safeguard Measures, Regulation of the Minister of Trade of the Republic of Indonesia Number 76 / M-DAG / PER / 12/2012 concerning Investigation Methods in Controlling Antidumping Measures and Compensation Measures and Trade Safeguard Measures, Regulation of the Minister of Trade of the Republic of Indonesia number 53 / M-DAG / PER / 9/2013, the Indonesian Anti-Dumping Committee has started an investigation.

If the definition of BjLAS refers to the definition of the Director General of Construction, Aluminum Zinc Coated Steel (BjLAS) is a cold rolled steel sheet and roll coated by hot dipping with aluminum alloy $50 \%-60 \%$, zinc $40 \%-50 \%$ and the rest is 
other elements. Usually in the world of steel business is called galvanized (GL). The technical specifications and test methods for this type of armored steel have been standardized with Mandatory SNI SNI 4096: 2007. Which is usually applied in the form of roof coverings; Wall coverings; Roof truss; Wall frame; The following are details of the items which is investigated by KADI:

Table 1.

Canai Lataian products of steel and non-alloy steel with a width of less than $600 \mathrm{~mm}$, clad in gilded, coated in ingout or otherwise

\begin{tabular}{lccc}
\hline No & HS Code & Description of goods & Import Duty \\
\hline $\mathbf{6 0 8 6}$ & 7210.61 .11 & $\begin{array}{c}\text { The thickness does not exceed } \\
1.2 \mathrm{~mm}\end{array}$ & $20 \%$ \\
$\mathbf{6 1 6 3}$ & 7212.50 .23 & $\begin{array}{c}\text { Loop and trip with a width not } \\
\text { exceeding 25 mm }\end{array}$ & $20 \%$ \\
$\mathbf{6 1 6 4}$ & 7212.50 .24 & $\begin{array}{c}\text { Another sipmai trip, Universal } \\
\text { Plate }\end{array}$ & $20 \%$ \\
$\mathbf{6 1 6 5}$ & 7212.50 .29 & Etc; & $20 \%$ \\
\hline \multicolumn{4}{c}{ Source: Minister of Finance Regulation No 6/PMK.010/2017(Year 2017) } \\
\end{tabular}

Table 2.

Canai Lataian products of other alloy steel with a width of $600 \mathrm{~mm}$ or more, in the form of rods and small rods, hollow drills, of alloy or non-alloy steel

\begin{tabular}{cccc}
\hline No & HS Code & $\begin{array}{c}\text { Description of } \\
\text { Goods }\end{array}$ & Import Duty \\
\hline $\mathbf{6 3 0 8}$ & 7225.99 .90 & Others; & $0 \%$ \\
$\mathbf{6 3 2 0}$ & 7226.99 .19 & Others; & $5 \%$ \\
$\mathbf{6 3 2 2}$ & 7226.99 .99 & Others; & $5 \%$ \\
\hline \multicolumn{4}{c}{ Source: Minister of Finance Regulation No 6/PMK.010/2017 (Year 2017) } \\
\hline
\end{tabular}

Formulation of the Problem

1. What is the legal action taken by Indonesia against dumping by the People's Republic of China and Vietnam in trading BjLAS products in Indonesia?

2. What are the legal consequences of dumping carried out by the People's Republic of China and Vietnam in the trade of BjLAS products in Indonesia?

\section{Purposes}

To find out, understand, consider and take appropriate legal remedies that can be done by Indonesia against dumping actions committed by China and Vietnam and their legal consequences.

\section{RESEARCH METHODS}

This research comes from curiosity (niewgierigheid) to find the answers to an actual problem. A scientific research is carried out to find the truth of the object under study in a manner recognized by peer scientists in the field of expertise (intersubjective), so that the results of the research are recognized for its scientific nature (etenschappelijkheid), so the truth can be traced back by colleagues who are interested and things that are new (nieuw moet zijn) ${ }^{1}$. In legal research, itnis about how to know not just know-about, because what is sought is a solution to an existing legal issue. According to Cohen, it takes the ability to identify legal problems, carry out legal 
reasoning, analyze the problems faced and solve these problems (Willems, 2012:17) Consists of:

\section{Approach}

The statue approach is an important approach in normative legal research, because it serves as a basis for guidance or roadmap for legal steps to be taken to answer the formulation of problems in this scientific paper, so the suitability and consistency between international agreements, laws and or regulations can be studied. Then the conceptual approach (conceptual approach) is a view that departs from the views and doctrines that have developed in legal science related to dumping developments and world trade organizations. So with that the authors choose a statutory and conceptual approach in this study.

\section{Legal Material}

\section{Primary Legal Material}

Primary legal material is a legal entity that is authoritative in nature, which means that it has authority such as: laws, official records or minutes in the process of making laws and judges' decisions. The primary legal materials that will be used in this paper are:

a) Agreement on Implementation of Article VI GATT 1994 (Anti-Dumping Code).

b) Law number 7 of 1994, concerning Ratification of the Agreement Estabilishing the World Trade Organization (State Gazette of the Republic of Indonesia of 1994 Number 57, Supplement to the State Gazette of the Republic of Indonesia Number 3564); Jakarta.

c) Law number 17 of 2006, amendments to Law number 10 of 1995 , concerning Customs (State Gazette of the Republic of Indonesia of 2006 Number 93, Supplement to the State Sheet of the Republic of Indonesia Number 4661); Jakarta.

d) Government Regulation number 34 of 2011, concerning Antidumping Measures, Compensation Measures and Security Measures (State Gazette of the Republic of Indonesia of 2011 Number 66, Supplement to the State Sheet of the Republic of Indonesia Number 5225); Jakarta.

e) Regulation of the Minister of Trade of the Republic of Indonesia number 76 / MDAG / PER / 9/2013, amendments to the Regulation of the Minister of Trade of the Republic of Indonesia number 76 / M-DAG / PER / 12/2012 regarding Investigation procedures in the context of Imposing Antidumping Measures, Compensation Measures and Trade Security.

\section{Secondary Legal Materials}

Secondary legal materials are all publications on law that are not official documents, but in the form of legal publications which include: law books, legal dictionaries, legal journals or court decisions. ${ }^{1}$ However, theses, theses and dissertations are also secondary laws, which in the process of writing provide directions as well as inspiration for the author in compiling this scientific paper (Willems, 2012:17).

\section{Non-legal Materials}

Non-legal materials serve as an extension of writing in identifying and analyzing facts accurately and understanding the legal issues at hand, but sometimes complex problems are deemed necessary for a deeper understanding of this knowledge. This 
can be in the form of books on economics, philosophy, anthropology, history, trade, culture and all aspects covering the legal issues faced. In addition to books, journals and research reports as long as they have relevance to the research topic (Grasstek, $2013: 303)$.

\section{Legal Entity Analysis}

According to Peter Mahmud Marzuki, in carrying out legal research we can take the following steps:

a) Identifying legal facts and eliminating things that are not relevant to solve legal issues that are to be obtained:

b) Collecting legal materials and non-legal materials that also relevance;

c) Review legal issues, based on the material collected;

d) Draw conclusions in the form of arguments that answer legal issues; and

e) Provide a prescription based on the arguments that have been built in the conclusion.

\section{FINDING AND DISCUSSION}

\section{Dumping}

\subsection{The Meaning of Dumping}

Dumping in the English dictionary is linguistically derived from the word Dump; is "to put down or drop someting in a careless way" which means "to drop something in a different way" while Dumping: is "the practice of selling goods in another country so cheaply that companies in that country cannot compete fairly" which means " the practice of selling goods in another country so cheaply that companies in that country cannot compete fairly" (Grasstek. ${ }^{1}$

In Black Law's legal dictionary, "dumping is the act of selling a large quantity of goods at less than fair value; also, selling goods abroad at less than the mareket price at home". ${ }^{1}$ And dumping in the economic dictionary is the sale of goods on a large scale in other marketing areas, usually abroad, which is lower than domestic (Willems, 2012:17).

Several legal experts also provide an understanding of dumping. According to Folsom, "dumping is as selling goods abroad at lower prices than the same items at home or not at its normal price". ${ }^{1}$ According to Huala Adolf, in her book entitled Principles of International Trade Law explains that "Dumping is the sale of a product abroad at a price lower than the domestic price or the price in the market in the country that imports the goods" (Willems, 2012:17).

Whereas from the some of the definitions of dumping above, it can be concluded that dumping is a practice of price discrimination which is lower in selling price by exporters who are carried out outside their country or third country with the aim of making a profit, thus impacting on unfair prices for the Importing Country Industry.

\subsection{Forms of Antidumping Action}

\section{Offensive Antidumping Action}

Offensive (i.e the improved market accesss that they aim to achiev in the market of their trading partner (Grasstek, 2013 : 303). Offensive trade instrument aim to improve market acces for EU operators in third countries (i.e the Trade Barriers Regulation [No. 3286/94], enable EU businesses to request that the Erupean Commission 
investigate and challenge market access barriers in forgein markets [including those applicable to goods, services and intellectual property rights], using WTO or other mechanism if necessary (Grasstek, 2013 : 303).

From this explanation it can be interpreted that Offense Antidumping Measures exist as a form of security on foreign market access. Or it can make an application to a third country market authority institution. One of them is by conducting an investigation on the existence of non-tariff protection and barriers that occur in foreign markets that are detrimental to the Domestic Industry.

\section{Defensive Antidumping Action}

Defensive Interest (i.e the protective barriers in their own markets that the affected industries demand be preserved). Defensive trade instrument aim to protect the EU market against the import of product causing injury into EU producers of the same similar or product. The most prominent defensive trade mechanism are the antidumping, anti-subsidy, and safe guard instrument (Grasstek, 2013 : 303).

Antidumping measures in the form of trade protection (Defensive) are carried out if the Domestic Industry in the domestic market experiences losses to similar goods exported by other countries at prices below normal / unfair so that it has a bad impact (causal link) for the Domestic Industry which is already established in developing its business. and those who will establish an Industry for this reason, protect the domestic market against imported products that cause losses to similar products by taking antidumping, anti-subsidies measures.

\subsection{Dumping Criteria}

The existence of anti-dumping serves as a resistance to import prices that are carried out at unfair prices to other markets. Referring to the Anti-dumping Code 1994, before the policy on anti-dumping measures was born, there were at least 3 (three) things that must be found: First, we must find evidence of goods that are suspected of dumping by foreign producers. Second, there is a domestic industry of similar goods that is experiencing threats or losses. And Third, it was found that dumping was the cause of the disadvantage. ${ }^{5}$ The following is an explanation of the sections in chapter by chapter:

1. Like Products are all aspects such as physical character, technique, chemical composition, and usage. As for testing of similar goods, it can be seen from Physical Characteristics, Chemical Elements, Machine Technology, Production Process, Quality Level, Function or Application, Consumer Tendency, Market Segments, Costs, Prices, and Groups, this is the basis for whether the goods suspected of dumping is a similar item (Willems $2012: 17$ ).

2. Sales of goods are less than normal Value

Dumping goods is an act of selling a country's product which is less than its normal value.

3. Injury is meant the impact of sales under normal value which results in material loss, threat of loss, or a hindrance to similar domestic Industries that are willing to stand up and be detrimental to Industries that are in operation (Willems 2012 : 17).

To identify a dumping act that causes material loss or not which becomes evidence it must be based on the proof of submission of that causality, namely: the effect of the volume of imports of dumping goods on similar goods on the domestic market, then the effect of the price of dumping goods on similar goods in the 
country and losses suffered by the domestic industry due to the dumping goods (Willems 2012 : 17).

Meanwhile, testing of domestic industry losses can be seen through the following indicators: Decrease in Domestic Sales, Decrease in Profits, Decrease in Production, Decrease in Market Distribution, Decrease in Productivity, Rate of Return on Investment; Utilization of production capacity; Domestic prices, etc (Willems 2012: 17).

4. Domestic Industry is a domestic producer that produces similar goods or a group of producers who collectively produce a large part of domestic production (Willems 2012 : 17). Anti-dumping disputes begin when the Producers or Domestic Industry alone or under an association are deemed sufficient (meet the minimum standards) to carry out an investigation under a government agency (Willems 2012:17).

5. There is a causal link between goods which sold by importers at under normal prices and losses incurred by countries between countries. It must be based on a test covering all economic factors in identifying the losses experienced by the domestic industry as stated earlier.

\section{Application and Process of Antidumping Investigation 2.1 Parties to the Anti-dumping Action}

\section{Interested party}

Interested parties in anti-dumping actions are exporters, producer exporters, the government of the exporting country, applicants or the Domestic Industry, importers, who are involved in the investigation of Antidumping Measures.

\section{Indonesian Anti Dumping Committee (KADI)}

KADI as a technical agency that deals with the importation of dumping goods or contains subsidies that result in losses to the domestic similar goods industry has several functions, duties and positions that are responsible to the Minister of Trade of the Republic of Indonesia and is assigned a special task to handle problems related to efforts to overcome import of dumping goods and goods containing subsidies, all of which are included in the State Revenue and Expenditure Budget under the Ministry of Trade (Willems 2012 : 17).

\section{Domestic Industry}

Domestic Industry (IDN) is a domestic producer as a whole of similar goods or the cumulative production (association) is a large proportion of the total production of similar goods (Willems 2012 : 17). IDN is deemed to represent if the producer or domestic association of similar goods is if the production is more than $50 \%$ (fifty percent). Investigation can only be carried out if the applicant's production or the applicant's or those who participate in support amounts to $25 \%$ (twenty five percent) of the domestic production of similar goods. And Investigation cannot be carried out if the dumping margin value is below $2 \%$ (two percent) of the export price and / or the import volume of dumping goods is less than $3 \%$ (three percent) or $7 \%$ (seven percent) of the volume of dumping goods carried out by several countries. cumulatively or total imports of similar goods. If the requirements submitted are not yet complete, the 
applicant will be given the opportunity to complete the data and information request (Willems 2012 : 17).

\subsection{Requirements for Application for Antidumping Measures Formal Requirements}

The process of submitting an inquiry request must be submitted in writing in Indonesian to the Chairman of KADI with information stating the identity of the applicant containing at least: the name of the company; office address; factory address; office phone number; factory telephone number; fax number; and the name and telephone number of the specific contact person.

Apart from that, other information is related to the names and addresses of exporters and / or producer exporters and importers which are known completely and correctly as well as a complete description of the imported goods accused of dumping and / or containing subsidies and the tariff heading number (ten digits in accordance with the provisions of the legislation in the field. customs)

\section{Material Requirements}

The application for these requirements must be made in writing and must be in Indonesian language and submit data and / or information in writing regarding: First, General Information (background of the request for investigation, data on the application containing; name, full address and telephone number; company office and factory, deed of company establishment, industrial business permit) information about the domestic industry, description and process of goods suspected of being dumping or subsidized, exporting countries and producers / exporters, known importers.

Second, Alleged dumping and or, normal calculation, and export price containing: Total production of similar goods produced by applicants and other domestic producers; The volume and value of imported goods accused of dumping and / or subsidies for at least the last three years; Allegations of dumping and / or subsidies covering (normal value, export price, amount of dumping margin); Loss; and Causal relationship between dumping goods and losses;

Third, the analysis of the losses suffered by the applicant contains: the applicant's losses, import data from countries accused of dumping and / or subsidies, development indicators (production, installed capacity, utilization, supplies, sales, exports) in the country, price undercutting, price depression, and price support., domestic industrial material losses due to dumping goods (decrease: domestic sales, profit, production, capacity utilization, market share, productivity); disruption, return on investment, cash flow, changes in domestic prices, increased inventory, layoffs, decreased wages, decreased growth, and clausal relationships between dumping and / or subsidies, with losses and other factors causing losses. And fourth, fulfilling the requirements as defined in the IDN in the Minister of Trade-RI Competition. ${ }^{5}$

\subsection{Antidumping Investigation StagePengujian Bukti Awal}

Investigations can be carried out on the basis of requests from the Domestic Industry and KADI Initiatives themselves. Preliminary evidence testing is carried out if the investigation process is based on an application from the Domestic Industry for similar goods, in which KADI checks the requested file for 30 days since the file is received. The testing process includes, among other things, the completeness of the documents in accordance with the terms and conditions, the strength of evidence of dumping, the type of goods, the relationship in question between dumping and losses suffered by the 
Domestic Industry. If the investigation is carried out on the initiative, then the test is carried out as a basis for KADI to continue the next steps

\section{Early Notification}

Prior to carrying out an investigation, KADI is obliged to provide early notification to representatives of the accused country of embassies, namely China and Vietnam at least 2 (two) weeks before the investigation begins.

\section{Announcement or Initiation}

KADI will announce the Government's announcement about the commencement of the investigation through national newspapers and press releases. The announcements will be notified to interested parties, including:

a) Exporters, foreign producers, or importers of goods under investigation or associations whose majority members are exporters, producers or importers of Chinese and Vietnamese BjLAS;

b) Governments of exporting countries (China and Vietnam);

c) Domestic producers of similar goods, or domestic producer associations where the majority of members produce similar goods;

The investigation process carried out by KADI on the BjLAS dumping carried out by China and Vietnam only reached the Questionnaire Distribution stage and the investigation process was secret and closed so that the results of the investigation carried out by KADI had not been completed and could not be published. However, if the results of the KADI investigation find indications of dumping, then KADI will provide recommendations to the Minister of Trade to be followed up in obtaining considerations in the context of national policies with relevant Ministers or nonministerial government agencies (Willems 2012 : 17).

\section{Preliminary Investigation}

KADI will conduct an investigation to obtain evidence about the existence of dumping which results in losses to the domestic industry by:

a) Send notification letters to related parties, namely: Representatives of the Government of China and Vietnam in Jakarta, Representatives of the Government of Indonesia in China and Vietnam, Producers or exporters in China and Vietnam, and importers of similar goods in the country. If there are applicants in different cases, the applicants are also included.

b) Receiving questionnaires, researching, receiving evidence, completing data, receiving explanations, analyzing answers to questionnaires, and other data from overseas producers to determine the amount of dumping margin.

c) Verify applicants and domestic importers, foreign producers or exporters who have provided complete information with answers to questionnaires. The purpose of verification is to ensure the truth of the data submitted based on accurate evidence.

d) Analyze the results of verification and make conclusions about the results of the dumping investigation whether or not evidence of dumping is found and the loss caused by dumping goods.

e) If no evidence is found, KADI will stop the investigation process and announce the termination, but if dumping is found then a temporary measure will be taken.

\section{Temporary Measures}

Temporary measures taken in the form of Temporary Anti-Dumping Import Duty (BMADS) by KADI by providing a temporary report on the results of the investigation to the Minister if sufficient preliminary evidence is found regarding the existence of 
Dumping goods that cause losses and is notified to the exporter and / or producer exporter directly through the exporting country, Applicant or IDN and Importer.

With a note that if the dumping margin has been found but the value is very small deminimis, KADI will terminate the investigation, what is meant by deminimis dumping margin is less than $2 \%$ (two percent) of the export price. Besides that, KADI also proved whether the dumping had an impact on IDN or not so that it suffered a loss

\section{Advanced Investigation}

Adjustment measures can be carried out by KADI or exporters and / or producer exporters no later than seven days after the imposition of BMADS or a preliminary report on the results of the investigation by means of price adjustments or cessation of export of dumping goods. However, it can be rejected or accepted if the results of the adjustment action no longer have a negative impact. The bid for adjustment action is submitted no later than 7 (seven) days from the imposition of BMADS or the preliminary report on the results of the investigation if there is no imposition of BMADS.

If KADI approves the adjustment action, it will be stated in a memorandum of understanding with the exporter and / or producer exporter conveying the implementation of temporary measures to KADI periodically and is willing to be verified for the implementation of the adjustment action besides the investigation will be postponed or terminated, but if there is a violation of the note agreement then will be subject to Temporary Action or KADI continue the investigation. And if KADI rejects the offer, the adjustment measures will be submitted in writing to the exporter and / or producer exporter.

\section{End of Investigation or Imposition of Anti Dumping Duties}

KADI will make a determination in the final stage of the investigation, whether or not there has been dumping that was detrimental to IDN. Through the analysis, KADI will calculate the amount of dumping margin between the normal value and the export value of dumping goods which must be compared with the export value at the same level of trade which will determine the BMAD amount.

The imposition of BMAD began since the enactment of the Decree of the Minister of Finance on the imposition of BMAD on BjLAS products from China and Vietnam which will later be used as the basis for the Director General of Customs and Excise as part of the Minister of Finance who carries out BMAD collection based on SE Director General of Customs and Excise No. SE-19 / BC1997 concerning Guidelines for Implementation of Anti-Dumping Duties if proven to carry out dumping in accordance with the provisions.

\section{Judicial Review}

Reconsideration can be carried out at KADI's own request or initiative. Applications are submitted no later than 12 (twelve) months after the entry into force of BMAD by using Indonesian in writing, however, BMAD can be reviewed based on requests from exporters and / or producer exporters or domestic Industry and / or importers who are cooperative in the investigation process, or requests from exporters and / or producer exporters who do not export dumping goods prior to the imposition of BMAD. The review consists of the Interim Review and the Sunset Review along with the explanation: ${ }^{5}$

Interim Review is proposed by exporters and / or producer exporters to stop, not to be imposed and to carry out the BMAD amount. However, this application may also be rejected by KADI if it is proven that dumping of goods is proven to be detrimental to 
the domestic market. This can be done twelve months after Determination of BMAD (Willems 2012 : 17). Sunset Review is submitted by the Petitioner or the Domestic Industry to request an extension of BMAD funding, whether accompanied by a change in the amount or not. It can only be done twelve months after Determination of BMAD (Willems $2012:$ 17).

\section{International Trade Dispute Resolution}

In practice, international trade does not just go smoothly, sometimes accusations of dumping that are considered by other countries to be true are not true and have an impact on the imposition of BMAD. So the purpose of the imposition of BMAD is actually causing loss to producing countries and creating unfair prices for producers from exporting countries. If this happens, then the WTO forum can be raised through the industrial player country which is subject to BMAD, in accordance with the provisions in the GATT that the state can object to the producer whose verdict is to The Committee on Antidumping Practices (Willems 2012 : 17). Under The Dispute Settlement Body (DSB) (Willems 2012 : 17).

\section{CONCLUSIONS}

The legal effort made by Indonesia against Dumping by China and Vietnam in BjLAS Product Trade is to take anti-dumping action in the form of a defensive, based on Government Regulation Number 34 of 2011 by conducting an investigation of dumping goods first as a basis for consideration of determining dumping under the Indonesian Anti Dumping Committee (KADI) to prove that the BjLAS sold by China and Vietnam are dumping goods or not. In which the investigation was carried out on the basis of KADI's own initiative. KADI considers that the Domestic Industry needs to be assisted because it experiences losses. The investigation process has reached the stage of distributing questionnaires. The Adjustment and Review Efforts can be made in the form of requests by Exporters, Domestic Industry, Cooperative Importers during the investigation or KADI's own initiative. By submitting an application for a Judicial Review in the form of an interim review to terminate, impose, not be imposed or change the BMAD amount.

The legal consequence of the Dumping Practices carried out by China and Vietnam in the sale of BjLAS products in Indonesia is that the temporary BMAD is imposed if it is still in the investigation process and deemed necessary. Then when it is seen that the indicators of the goods are proven to be dumping, the BMAD is imposed after the investigation is completed with the issuance of a Regulation of the Minister of Finance which contains the amount of duty imposed in accordance with the predetermined amount of the final dumping margin and the period of imposition of BMAD on BjLAS products from China and Vietnam. If in the stipulation of the Regulation of the Minister of Finance of China and / or Vietnam, there is an objection that dumping was not carried out, then the two countries can negotiate in bilateral and / or multilateral relations. However, if an agreement is not found between the two parties and remains adamant in their respective stances, China and Vietnam can file objections or court evidence under the Dispute Settlement Body (DSB) in the International Trade Organization, considering that all three are member states of the International Trade Organization. 


\section{REFERENCES}

Agreement on Implementation of Article VI General Agreement on Tariff and Trade 1994 (Anti-Dumping Code).

Arnoud R Willems, Sven De Knop, and Jeremle Charles (Sidley Austin LLP), The Handbook of Trade Enforcement 2012 (European Commision), Global Competition Review.

Badan Pusat Statistik, membaca "Ekspor Besi dan Baja menurut tujuan negara utama periode 2012-2017", http://www.bps.go.id/staticable/2019/02/27/2033/eksporbesi-baja-menurut-tujuan-negara-utama-2012-2017.html [diakses 8 september 2019].

David Held and Anthony McGrew, Globalization Theory: Aproach and Controversies (Cambridge: Polity, 2007), hlm 15-35

Direktorat Bina Kelembagaan dan Sumber Jasa Konstruksi, Direktorat Jendral Bina Konstruksi, Kementrian Pekerjaan Umum dan Perumahan Rakyat. Katalog Produk Baja Ringan Konstruksi 2018 (edisi pertama: cetakan pertama). Oktober 2018.

Cambridge International Dictionary of English, Cambridge Unviersity Press, Cambridge, 1995.

Carig Van Grasstek, History and the Future of World Trade Organization, Published by World Trade Organization; 2013.

Christoper Barutu, Ketentuan Antidumping, Subsidi, dan Safeguard, (Bandung: Citra Aditya Bakti, 2007).

Henry Campbell Black, Black's Law Dictionary, West Publisihing Co, 1979.

Huala Adolf, Prinsip Hukum Perdagangan Internasional, Refika, Bandung, 2018.Mark Skousen, Teori-teori Ekonomi Modern, (Jakarta: Pernada, 2001).

John H. Jackson, International Economic Law (ed) (R. Berhart, 1997).

Jonaedi Efendi, Metode Penelitian Hukum dan Empiris, Kencana, Jakarta, 2016.

Mark Wu, “Antidumping in Asia’s Emerging Giants”, Harvard International Law Journal Vol.53, Number 1, (Winter 2012).

Peraturan Pemerintah nomor 34 tahun 2011, tentang Tindakan Antidumping, Tindakan Imbalan dan Tindakan Pengamanan (Lembar Negara Republik Indonesia Tahun 2011 Nomor 66, Tambahan Lembar Negara Republik Indonesia Nomor 5225); Jakarta.

Peraturan Mentri Perdagangan RI nomor 76/M-DAG/PER/9/2013, perubahan atas Pertauran Mentri Perdagangan RI nomor 76/M-DAG/PER/12/2012 tentang tata cara Penyelidikan dalam rangka Pengenaan Tindakan Antidumping, Tindakan Imbalan, dan Pengamanan Perdagangan.

Peter Mahmud Marzuki, Penelitian Hukum (Edisi Revisi), Prenada Media Group, 2016.

Ralph Folsom. International Bussiness Transaction. (St.Paul,minn, 2000). 
Sri Redjeki Hartono. Kapita Selekta Hukum Ekonomi, Bandung: Bandar Maju, 2000.

Tan Ah Young: Secertary General, membaca "Performance of the ASEAN Iron and Steel Industry in 2017", South East Asia Iron and Steel Insitute (SEAISI), 2017.

Yulianto Syahyu, Hukum Antidumping di Indonesia, (Jakarta: Ghalia, 20014).

Yustinus Andri DP, membaca "Dugaan Dumping: RI Selidiki Baja Lapis Almunium Seng Asal Cina \& Vietnam" bisnis.com https://ekonomi.bisnis.com/read/20190828/12/1141997/dugaan-dumping-riselidiki-baja-lapis-aluminium-seng-asal-china-vietnam, [diakses 8 september 2019]. 